\title{
ANALISIS PERUBAHAN PENGGUNAAN LAHAN SEKITAR DANAU LIMBOTO DI KABUPATEN GORONTALO
}

\author{
Indriani Umar ${ }^{1}$, Agam Marsoyo², Bakti Setiawan ${ }^{3}$ \\ ${ }^{1}$ Mahasiswa, Departmen Teknik Arsitektur dan Perencanaan, Fakultas Teknik, UGM \\ ${ }^{2,3}$ Dosen, Departmen Teknik Arsitektur dan Perencanaan, Fakultas Teknik, UGM \\ Email: indriumar0812@gmail.com
}

\begin{abstract}
ABSTRAK
Danau Limboto di Kabupaten Gorontalo telah ada sejak tahun 1932 dengan luas \pm 7.000 Ha. Pada tahun 1991 luas danau menyusut menjadi $\pm 3.644,5$ Ha dan tahun 2017 luas danau kembali mengalami penyusutan menjadi $\pm 2.693,9 \mathrm{Ha}$. Tujuan penelitian ini adalah untuk mengidentifikasi jenis perubahan penggunaan lahan danau menjadi lahan bukan danau dan proses perubahan penggunaan lahan di sekitar Danau Limboto. Metode yang digunakan yaitu analisis overlay peta citra Landsat kawasan sekitar Danau Limboto menggunakan Sistem Informasi Geografis (SIG) kemudian dijelaskan secara deskriptif kualitatif untuk menjelaskan jenis dan proses perubahan penggunaan lahan disekitar Danau Limboto dari tahun 1991 sampai dengan 2017. Metode pengumpulan data yaitu studi data sekunder terkait peta citra Landsat wilayah sekitar Danau Limboto tahun 1991, 2001, 2015, dan 2017 dan juga observasi lapangan serta wawancara guna mengklarifikasi perubahan penggunaan lahan yang terjadi di sekitar Danau Limboto dari tahun 1991 - 2017. Hasil penelitian ini menunjukkan bahwa dalam kurun waktu 26 tahun (1991 - 2017), telah terjadi perubahan penggunaan lahan danau di sekitar Danau Limboto sebesar $\pm 936,56$ Ha menjadi lahan pertanian dan perkebunan, $\pm 14,29$ Ha menjadi lahan permukiman, dan $\pm 0,35$ Ha menjadi kawasan wisata. Adapun proses perubahan penggunaan lahan secara fisik di sekitar Danau Limboto yaitu: (1) lahan danau berubah menjadi rawa kemudian berubah menjadi lahan pertanian (lahan basah dan lahan kering) dan perkebunan (kelapa); (2) lahan danau menjadi rawa kemudian menjadi lahan pertanian (lahan basah dan lahan kering) dan kemudian berubah menjadi lahan permukiman; (3) lahan danau berubah menjadi lahan permukiman; dan (4) lahan danau langsung berubah menjadi kawasan wisata.
\end{abstract}

Kata Kunci: Kabupaten Gorontalo, Penyusutan Danau Limboto, Perubahan Penggunaan Lahan

\begin{abstract}
Limboto Lake in Gorontalo Province has been around since 1932 with an area of \pm 7,000 Ha. In 1991 the area of the lake shrank to $\pm 3,644.5 \mathrm{Ha}$ and in 2017 the area of the lake again declined to $\pm 2,693.9 \mathrm{Ha}$. The purpose of this research was to identify the type of change in lake land use into non-lake land and the process of changing land use around Limboto Lake. The method used is an overlay analysis of regional Landsat imagery maps around Lake Limboto using the Geographic Information System (GIS) and then described descriptively qualitatively to explain the types and processes of land use change around Limboto Lake from 1991 to 2017. Methods of data collection are secondary data studies related maps of Landsat area images around Limboto Lake in 1991, 2001, 2015, and 2017 and also field observations and interviews to clarify changes in land use that occurred around Limboto Lake from 1991 - 2017. The results of this research indicate that within 26 years (1991 - 2017), there has been a change in the use of lake land around Limboto Lake in the amount of \pm 936.56 $\mathrm{Ha}$ to agricultural and plantation land, $\pm 14.29 \mathrm{Ha}$ to become residential land, and $\pm 0.35 \mathrm{Ha}$ to become a tourist area. The process of changing the physical land use around Limboto Lake, namely: (1) lake land is turned into swamps and then turned into agricultural land (wetlands and dry land) and plantations (coconut); (2) the lake area becomes swamps and then becomes agricultural land (wetlands and dry land) and then turns into residential land; (3) lake land changes into residential land; and (4) lake land directly turns into a tourist area.
\end{abstract}

Keywords: Gorontalo Regency, Limboto Lake Depreciation, Land Use Changes

\section{PENDAHULUAN}

Lahan merupakan sumber daya alam yang mutlak dibutuhkan oleh manusia untuk menjalankan semua aktivitas dan sebagai tempat mencari penghidupan. Lahan adalah suatu daerah di permukaan bumi yang ciri-cirinya (characteristics) mencakup semua atribut yang bersifat cukup mantap atau yang dapat diduga bersifat mendaur dari biosfer, atmosfer, tanah, geologi, hidrologi, populasi tumbuhan dan hewan, serta hasil kegiatan manusia pada masa lampau dan masa kini, sepanjang pengenal-pengenal tadi berpengaruh secara signifikan atas penggunaan lahan pada waktu sekarang dan pada waktu mendatang (FAO dalam 
Arminah, 2012). Penggunaan lahan dipengaruhi oleh ekonomi, budaya, politik, sejarah dan faktor kepemilikan lahan di berbagai skala (Panwar, dkk, 2017). Oleh sebab itu, tidak sedikit lahan yang berubah peruntukkannya. Perubahan tersebut terjadi karena dua hal, pertama adanya keperluan untuk memenuhi kebutuhan penduduk yang makin meningkat jumlahnya dan kedua berkaitan dengan meningkatnya tuntutan akan mutu kehidupan yang lebih baik. Perubahan penggunaan lahan disuatu wilayah merupakan pencerminan upaya manusia memanfaatkan dan mengelola sumber daya lahan. Perubahan penggunaan lahan tersebut akan berdampak terhadap manusia dan kondisi lingkungannya.

Perubahan penggunaan lahan adalah bertambahnya suatu penggunaan lahan dari satu sisi penggunaan ke penggunaan lainnya diikuti dengan berkurangnya tipe penggunaan lahan yang lain dari suatu waktu ke waktu berikutnya atau berubahnya fungsi suatu lahan pada kurun waktu yang berbeda (Wahyunto, dkk, 2001). Menurut Koomen dan Stillwell dalam Krisnaningtyas dan Trimarmanti (2012), perubahan penggunaan lahan merupakan proses transformasi atau alokasi. Yunus (2001) mengemukakan bahwa proses dapat dikatakan merupakan urutan langkah-langkah dari satu peristiwa ke peristiwa yang lain yang berkembang menjadi sesuatu yang lain. Proses tersebut apabila dikaitkan dengan perubahan penggunaan lahan maka urutan atau langkahlangkah peristiwa peralihan fungsi atau perubahan penggunaan lahan dari suatu penggunaan awal ke penggunaan yang lain. Sinha dalam Yunus (2001) mengemukakan bahwa terdapat 2 (dua) proses perubahan pemanfaatan lahan atau penggunaan lahan yaitu proses perubahan pemanfaatan lahan atau penggunaan lahan secara horizontal dan secara vertical. Proses perubahan pemanfaatan lahan secara horizontal dapat dibedakan menjadi (3) tiga macam tipe perubahan, yaitu:

a. Proses perubahan penggunaan lahan dari lahan pertanian menjadi lahan permukiman,

b. Proses perubahan penggunaan lahan dari lahan pertanian menjadi lahan industrial,

c. Proses perubahan penggunaan lahan dari lahan pertanian menjadi lahan perkantoran pemerintah.

Adapun bentuk proses perubahan pemanfaatan lahan atau penggunaan lahan yang kedua adalah proses perubahan secara vertical yang tidak lain merupakan bentuk intensifikasi pemanfaatan lahan atau penggunaan lahan yang mana terdapat 3 (tiga) macam proses perubahan, yaitu: a. Perubahan vertikal dari bentuk pemanfaatan lahan atau penggunaan lahan pertanian buah-buahan menjadi lahan pertanian semusim,

b. Perubahan satu jenis pertanaman semusim menjadi dua atau tiga pertanaman semusim, dan

c. Perubahan dari dua jenis pertanaman semusim menjadi tiga atau lebih pertanaman semusim.

Perubahan penggunaan lahan di kawasan danau dapat menyebabkan berkurangnya luasan danau. Danau merupakan suatu ekosistem yang terdiri dari unsur biotik dan abiotik yang terletak di bentangan alam yang bukan merupakan suatu wilayah administrasi tetapi mempunyai nilai ekologis penting karena fungsinya sebagai kawasan resapan air, kawasan perlindungan setempat, kawasan konservasi tanah dan air, dan fungsi hidrologisnya.

Danau Limboto merupakan salah satu asset sumber daya alam yang terdapat di Provinsi Gorontalo khususnya Kabupaten Gorontalo yang memiliki peran penting dalam wilayah tersebut khususnya bagi masyarakat yang tinggal di sekitar Danau Limboto. Danau Limboto termasuk dalam kategori danau kritis menurut KLH. Hal tersebut dikarenakan penyusutan yang terus terjadi di Danau Limboto yang mengancam keberlanjutan dari danau tersebut. Sedimentasi dari 23 (dua puluh tiga) sungai yang masuk ke wilayah danau mengakibatkan penyusutan di Danau Limboto dan memicu perubahan penggunaan lahan pada lahan bekas penyusutan danau.

Luas Danau Limboto yang telah menyusut menjadi $\pm 3.644,5 \mathrm{Ha}$ pada tahun 1991 mengalami penyusutan pada tahun 2017 menjadi menjadi $\pm 2.693,9 \mathrm{Ha}$. Dalam rentang waktu 26 (dua puluh enam) tahun tersebut luas danau telah menyusut $\pm 950,5 \mathrm{Ha}$. Lahan bekas penyusutan danau tersebut kemudian mengalami perubahan penggunaan lahan dari lahan danau menjadi lahan bukan danau yang dengan kata lain terjadi perubahan penggunaan lahan dari lahan yang memiliki fungsi sebagai kawasan lindung berubah menjadi kawasan budidaya. Hal tersebut jika dibiarkan akan mengancam keberlanjutan dari Danau Limboto di masa yang akan datang. UU No 7 Tahun 2004 tentang sumber daya air menjelaskan tentang 
pentingnya konservasi sumber daya air termasuk danau untuk keberlanjutan kehidupan semua makhluk hidup di masa sekarang dan mendatang. Dalam UU tersebut juga dijelaskan terkait pendayagunaan dan pemeliharaan sumber daya air, pengendalian daya rusak air, serta penetapan zonasi wilayah danau dan sempadan danau yang berfungsi sebagai kawasan lindung. Selain itu dalam UU No 26 tahun 2007 tentang penataan ruang dijelaskan bahwa danau dan sempadan danau termasuk dalam kawasan yang memiliki fungsi lindung sehingga tidak dibenarkan adanya kegiatan yang bersifat budidaya diatas lahan tersebut seperti kegiatan pertanian dan permukiman.

Berdasarkan latar belakang tersebut maka perlu dilakukan penelitian terkait analisis perubahan penggunaan lahan di sekitar Danau Limboto seiring dengan penyusutan dan pendangkalan yang terjadi di Danau Limboto. Pada penelitian analisis terkait perubahan penggunaan lahan di sekitar Danau Limboto Kabupaten Gorontalo yang menjadi fokus dalam penelitian ini yaitu terkait seperti apa jenis perubahan penggunaan lahan yang terjadi di sekitar Danau Limboto dan proses perubahan penggunaan lahan secara fisik di sekitar Danau Limboto di Kabupaten Gorontalo.

\section{METODE PENELITIAN}

Penelitian ini dilakukan melalui pendekatan kualitatif dengan menggunakan bantuan peta time series dalam menjelaskan jenis dan proses perubahan penggunaan lahan di sekitar Danau Limboto dari tahun 1991 sampai dengan tahun 2017 yang diamati dalam titik waktu pengamatan yaitu tahun 1991, 2001, 2015, dan 2017. Metode analisis data yaitu dengan cara overlay peta citra Landsat wilayah sekitar Danau Limboto menggunakan Sistem Informasi Geografis (SIG). Berdasarkan analisis tersebut kemudian dijelaskan proses perubahan penggunaan lahan secara deskriptif kualitatif yang berdasarkan analisis overlay peta citra pada setiap tahun pengamatan (1991, 2001, 2015, 2017) yang kemudian dikonfirmasi dengan hasil observasi dan wawancara dengan informan dalam menjelaskan proses perubahan penggunaan lahan yang terjadi di sekitar Danau Limboto.

Menurut Moleong (2006), penelitian dengan metode kualitatif adalah penelitian yang bermaksud untuk memahami fenomena tentang apa yang dialami oleh subjek penelitian misalnya perilaku, persepsi, motivasi, tindakan, dan lainlain secara holistic dan dengan cara deskripsi dalam bentuk kata-kata dan bahasa, pada suatu konteks khusus yang alamiah dengan memanfaatkan berbagai metode alamiah. Lebih lanjut Moleong mengemukakan bahwa penelitian kualitatif dapat dimanfaatkan untuk meneliti sesuatu dari segi prosesnya.

Penelitian kualitatif yang mengandalkan manusia sebagai alat penelitian dalam usaha menemukan teoriteori dasar yang bersifat deskriptif. Proses penelitian yang dilakukan dalam penelitian ini yaitu meliputi tahapan pengumpulan data melalui observasi, wawancara, dan dokumentasi. Proses analisis data dan mengkonstruksi hasil analisis untuk menggambarkan jenis dan proses perubahan penggunaan lahan yang terjadi di sekitar Danau Limboto seiring penyusutan luas dan pendangkalan yang terjadi di Danau Limboto dari tahun 1991 sampai dengan 2017.

Unit amatan dalam penelitian ini adalah jenis dan proses perubahan penggunaan lahan seiring dengan penyusutan yang terjadi di Danau Limboto dari tahun 1991 sampai dengan tahun 2017. Unit analisis berupa lahan di sekitar Danau Limboto di Kabupaten Gorontalo yang dulunya merupakan lahan danau. Berikut ini merupakan peta lokasi wilayah penelitian di sekitar Danau Limboto yang meliputi 6 (enam) kecamatan di Kabupaten Gorontalo yaitu Kecamatan Tilango, Telaga Jaya, Telaga Biru, Limboto, Tabongo, dan Kecamatan Batudaa.

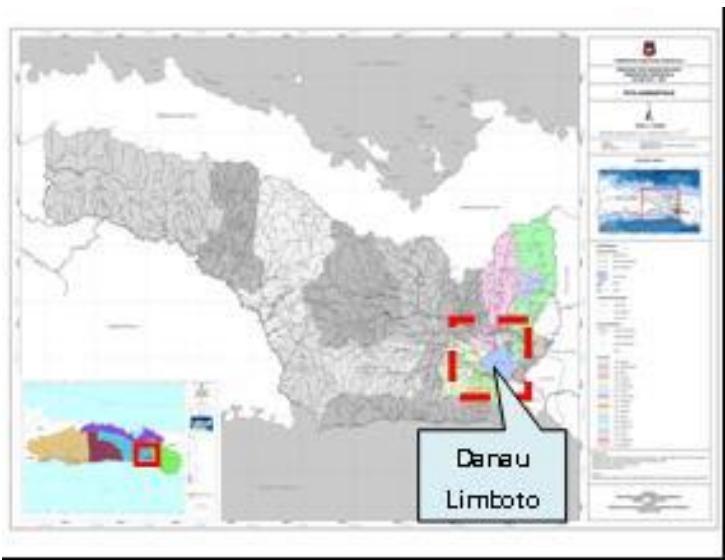

Gambar 1. Orientasi Lokasi Penelitian

Sumber: Dinas PU Kabupaten Gorontalo, 2018

Data yang digunakan dalam penelitian ini adalah peta citra Landsat wilayah sekitar Danau Limboto tahun 1991, 2001, 2015, dan 2017 untuk menggambarkan jenis serta proses perubahan penggunaan lahan yang terjadi di sekitar Danau Limboto dalam beberapa titik tinjauan waktu pengamatan. Selain 
menggunakan data dari peta citra satelit dalam penelitian ini juga menggunakan data yang berdasarkan dengan hasil observasi dan wawancara untuk mengkonfirmasi perubahan penggunaan lahan di sekitar Danau Limboto. Adapun pihak yang dijadikan informan dalam penelitian ini yaitu pemerintah, tokoh masyarakat, dan masyarakat yang tinggal di sekitar Danau Limboto.

Adapun variabel yang digunakan dalam penelitian untuk menjelaskan seperti apa perubahan penggunaan lahan yang terjadi di sekitar Danau Limboto yaitu terdiri dari 2 (dua) variabel: (1) jenis penggunaan lahan tahun 1991 dan 2017, dan (2) luas perubahan penggunaan lahan danau dari tahun 1991 sampai dengan tahun 2017. Selanjutnya untuk menggambarkan proses perubahan penggunaan lahan yang terjadi di sekitar Danau Limboto variabel yang digunakan yaitu jenis penggunaan lahan di sekitar Danau Limboto tahun 1991, 2001, 2015, dan 2017.

Analisis data dalam penelitian ini dilakukan secara spasial dengan menggunakan teknik overlay menggunakan software Arc GIS 10.2 terhadap peta penggunaan lahan di kawasan sekitar Danau Limboto khususnya pada lahan bekas penyusutan danau yang diambil secara time series dengan rentang waktu 26 (dua puluh enam) tahun, antara tahun 1991 - 2017 yang terbagi dalam 4 (empat) tahun pengamatan yaitu tahun 1991, 2001, 2015, dan 2017 untuk menggambarkan perubahan penggunaan lahan di kawasan sekitar Danau Limboto seiring dengan penyusutan luas dan pendangkalan yang terjadi di danau tersebut dalam kurun waktu 26 (dua puluh enam) tahun. Penggunaan 4 (empat) tahun amatan tersebut karena keterbatasan data yang ada dalam hal ini citra landsat yang berhasil dikumpulkan oleh peneliti hanya terbatas pada tahun 1991, 2001, 2015, dan 2017. Beradasarkan analisis overlay tersebut dapat dilihat jenis dan luas perubahan penggunaan lahan yang terjadi di sekitar Danau Limboto dari tahun 1991 sampai dengan tahun 2017. Selanjutnya, dilihat proses perubahan penggunaan lahan secara fisik yang terjadi di sekitar Danau Limboto di Kabupaten Gorontalo dalam 4 (empat) tahun yang menjadi titik tinjauan pengamatan.

\section{HASIL DAN PEMBAHASAN}

Pengolahan dan analisa data dilakukan dengan menggunakan teknik overlay peta citra satelit kawasan sekitar Danau Limboto tahun 1991, 2001, 2015, dan 2017 yang kemudian dari hasil analisis tersebut dijelaskan secara deskriptif kualitatif dengan berdasarkan data hasil observasi dan wawancara di lokasi penelitian guna untuk melakukan konfirmasi terkait jenis serta proses perubahan penggunaan lahan seiring penyusutan yang terjadi di sekitar Danau Limboto.

\section{Perubahan Penggunaan Lahan di Sekitar Danau Limboto (Tahun 1991 - 2017)}

Danau Limboto merupakan salah satu asset sumber daya alam yang dimiliki oleh Provinsi Gorontalo yang memiliki peran sebagai sumber pendapatan nelayan, penampung air hujan dan sumber pengairan bagi kawasan disekitarnya. Hal ini dapat terlihat dari jenis penggunaan lahan disekitar Danau Limboto yang mana didominasi oleh lahan pertanian dan permukiman. Danau Limboto terbentuk sejak tahun 1932 dengan luas $\pm 7000 \mathrm{Ha}$ dengan kedalaman $30 \mathrm{~m}$. Namun saat ini luas danau tersebut telah mengalami penyusutan yang disebabkan oleh sedimentasi sungai yang bermuara ke Danau Limboto. Selain itu kerusakan hutan pada hulu sungai juga turut menyebabkan lajunya sedimentasi yang masuk ke wilayah danau. Pada Gambar 5.1 dapat dilihat bahwa terjadi dalam kurun waktu beberapa tahun tersebut terjadi penyusutan luas wilayah danau dalam beberapa titik tinjauan waktu pengamatan yaitu tahun 1991, 2001, 2015, dan 2017.

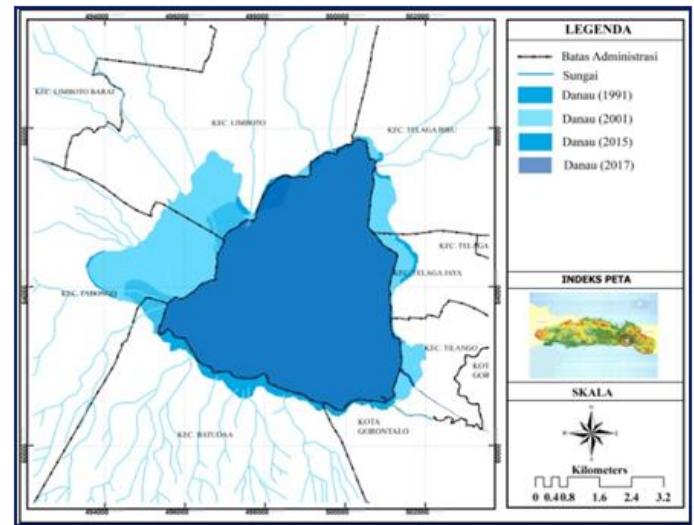

Gambar 2. Peta Penyusutan Luas Danau Limboto dari Tahun 1991 sampai dengan 2017 Sumber: Analisis Penulis, 2018

Berdasarkan Gambar 2 tersebut dapat dilihat bahwa dari waktu ke waktu (tahun 1991, 2001, 2015, 2017) telah terjadi penyusutan Danau Limboto. Hal ini berdasarkan hasil analisis digitasi peta citra Landsat pada tahun-tahun amatan tersebut yang menunjukkan bahwa luas danau dari 
tahun ke tahun menjadi berkurang seperti dalam grafik berikut ini:

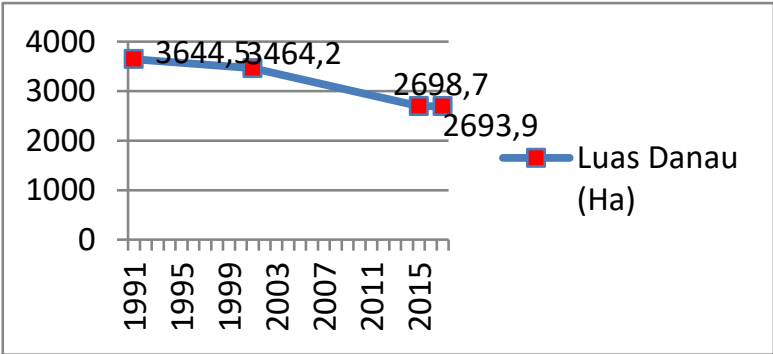

Gambar 3. Penyusutan Luas Danau Limboto dari 1991 sampai dengan 2017

Sumber: Analisis Penulis, 2018

Lahan bekas penyusutan danau tersebut kemudian berubah penggunaannya dari lahan danau menjadi bukan danau atau terjadi perubahan penggunaan fungsi dari lahan yang berfungsi sebagai kawasan lindung berubah menjadi kawasan budidaya. Lebih jelasnya perubahan penggunaan lahan pada lahan bekas penyusutan danau di sekitar Danau Limboto dapat dilihat pada Gambar 4 berikut ini.

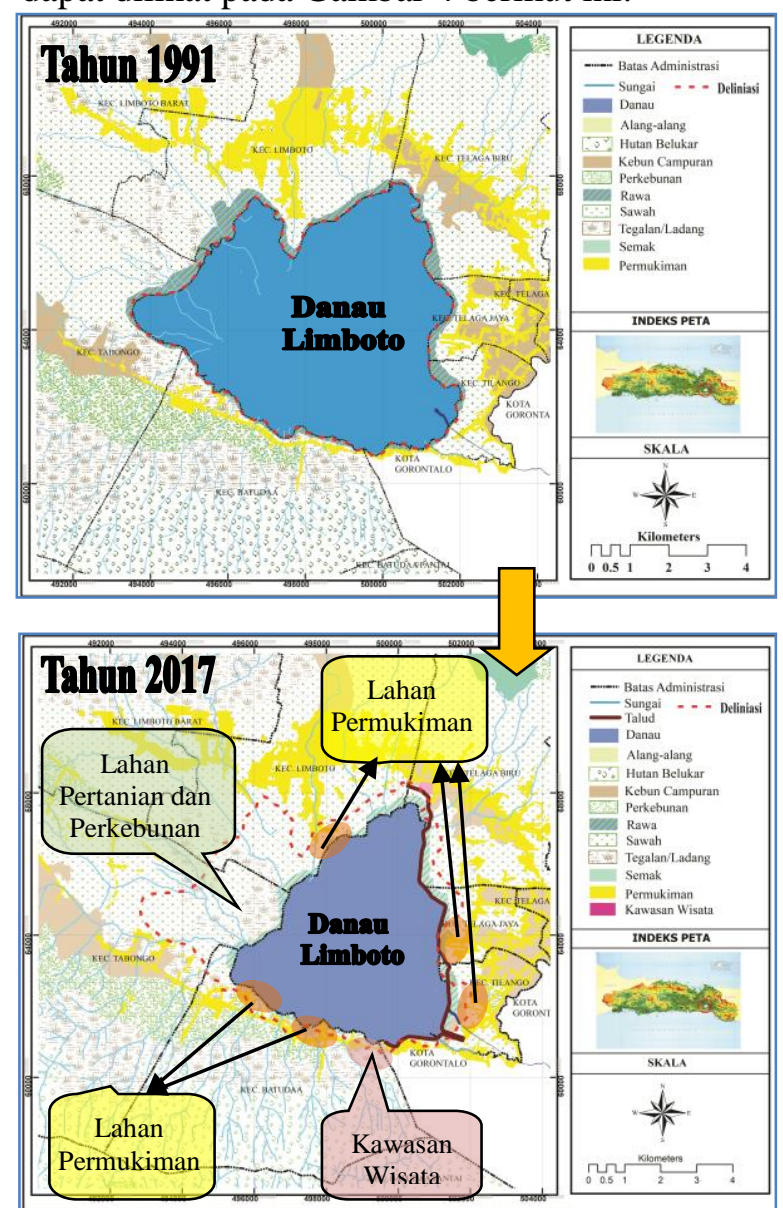

Gambar 4. Perubahan Penggunaan Lahan di Sekitar Danau Limboto dari Tahun 1991 sampai dengan tahun 2017

Sumber: Analisis Penulis, 2018
Pada Gambar 4 dapat dilihat bahwa terjadi penyusutan luas danau dari tahun 1991 sampai dengan 2017 yang kemudian lahan bekas penyusutan tersebut berubah penggunaannya menjadi lahan bukan danau (lahan pertanian dan perkebunan, lahan permukiman, dan kawasan wisata). Berdasarkan Gambar 4 tersebut juga dapat dilihat bahwa perubahan penggunaan lahan seiring penyusutan luas Danau Limboto yaitu perubahan penggunaan lahan dari lahan danau menjadi lahan bukan danau yang dalam gambar tersebut terlihat bahwa lahan yang awalnya danau berubah menjadi lahan pertanian dan perkebunan, lahan permukiman, dan kawasan wisata. Berdasarkan hasil analisis menggunakan Sistem Informasi Geografis (GIS) dapat dilihat luas perubahan penggunaan lahan danau menjadi lahan bukan danau yaitu pada tabel berikut ini.

Tabel 1. Jenis Perubahan Penggunaan Lahan Akibat Penyusutan Danau Limboto

\begin{tabular}{|l|c|c|c|c|}
\hline \multirow{2}{*}{$\begin{array}{c}\text { Jenis Penggunaan } \\
\text { Lahan }\end{array}$} & \multicolumn{2}{|c|}{1991} & \multicolumn{2}{c|}{2017} \\
\cline { 2 - 5 } & $\begin{array}{c}\text { Luas } \\
\text { (Ha) }\end{array}$ & $\%$ & $\begin{array}{c}\text { Luas } \\
\text { (Ha) }\end{array}$ & $\%$ \\
\hline Danau & 3644,5 & 100 & 2693,9 & 73,91 \\
\hline Non Danau & & & & \\
\hline $\begin{array}{l}\text { Pertanian dan } \\
\text { Perkebunan }\end{array}$ & & & 936,56 & 25,69 \\
\hline Permukiman & & & 14,29 & 0,39 \\
\hline Kawasan Wisata & & & 0,35 & 0,01 \\
\hline
\end{tabular}

Sumber : Analisis Penulis, 2018

Pada Tabel 1 dapat dipahami bahwa terjadi perubahan penggunaan lahan akibat penyusutan Danau Limboto yang menyebabkan lahan bekas penyusutan danau tersebut berubah jenis penggunaan lahannya. Hal tersebut dapat dilihat pada Tabel 1 yang mana pada tahun 1991 lahan yang masih merupakan danau, pada tahun 2017 berubah menjadi lahan bukan danau berupa lahan pertanian dan perkebunan, permukiman, dan kawasan wisata.

Berdasarkan hal itu, selanjutnya dilakukan analisis secara deskriptif kualitatif dengan berdasarkan hasil overlay dan digitasi peta citra satelit untuk melihat jenis penggunaan lahan pada tahun 1991, 2001, 2015, dan 2017. Hal tersebut dilakukan untuk menjelaskan proses perubahan penggunaan lahan secara fisik yang terjadi di sekitar Danau Limboto dari lahan danau menjadi lahan bukan danau 
baik dari lahan danau ke lahan pertanian dan perkebunan, lahan danau ke lahan permukiman, serta lahan danau ke kawasan wisata.

\section{Proses Perubahan Penggunaan Lahan Danau Menjadi Lahan Bukan Danau di Sekitar Danau Limboto} (Tahun 1991 - 2017)

Proses perubahan penggunaan lahan yang terjadi di sekitar Danau Limboto yang dikaji dalam penelitian ini dibatasi pada proses perubahan penggunaan lahan secara fisik. Analisis perubahan penggunaan lahan yang terkait dengan proses perubahan penggunaan lahan secara fisik pada kawasan di sekitar Danau Limboto yang dibatasi pada wilayah kecamatan di Kabupaten Gorontalo yang berbatasan dengan Danau Limboto. Adapun proses perubahan penggunaan lahan secara fisik yang terjadi di sekitar Danau Limboto di Kabupaten Gorontalo dapat dikelompokkan menjadi 3 (tiga) tipe perubahan penggunaan lahan yaitu proses perubahan penggunaan lahan danau menjadi lahan pertanian dan perkebunan, proses perubahan penggunaan lahan danau menjadi lahan permukiman, dan proses perubahan penggunaan lahan menjadi kawasan wisata.

\section{Danau Menjadi Lahan Pertanian dan \\ Perkebunan}

Berdasarkan hasil analisis pada Tabel 1 tentang jenis perubahan penggunaan lahan pada lahan bekas penyusutan danau dapat dilihat bahwa perubahan penggunaan lahan danau yang signifikan yaitu perubahan penggunaan lahan danau menjadi lahan pertanian dan perkebunan yang mana dalam kurun waktu 26 (dua puluh enam) tahun yaitu dari tahun 1991 sampai dengan tahun 2017 terjadi perubahan penggunaan lahan danau menjadi lahan pertanian dan perkebunan sebesar 956,36 $\mathrm{Ha}$ atau sekitar 25,76\%. Perubahan lahan danau menjadi lahan pertanian baik pertanian lahan basah (sawah), pertanian lahan kering (kebun campuran dan tegalan) maupun perkebunan (kelapa) terjadi secara bertahap seiring dengan penyusutan yang terjadi dalam setiap tahun pengamatan yaitu tahun 1991, 2001, 2015 dan 2017 seperti dalam gambar 5.

Berdasarkan gambar 5 dapat dilihat bahwa terjadi proses perubahan penggunaan lahan secara fisik pada lahan bekas penyusutan Danau Limboto. Pada gambar 5 (a) dapat dilihat jenis penggunaan lahan di sekitar Danau Limboto pada tahun 1991. Selanjutnya pada tahun 2001 (gambar 5 (b)) terjadi perubahan penggunaan lahan dari lahan danau berubah penggunaannya menjadi lahan pertanian berupa rawa tepatnya pada kawasan tepian Danau Limboto.

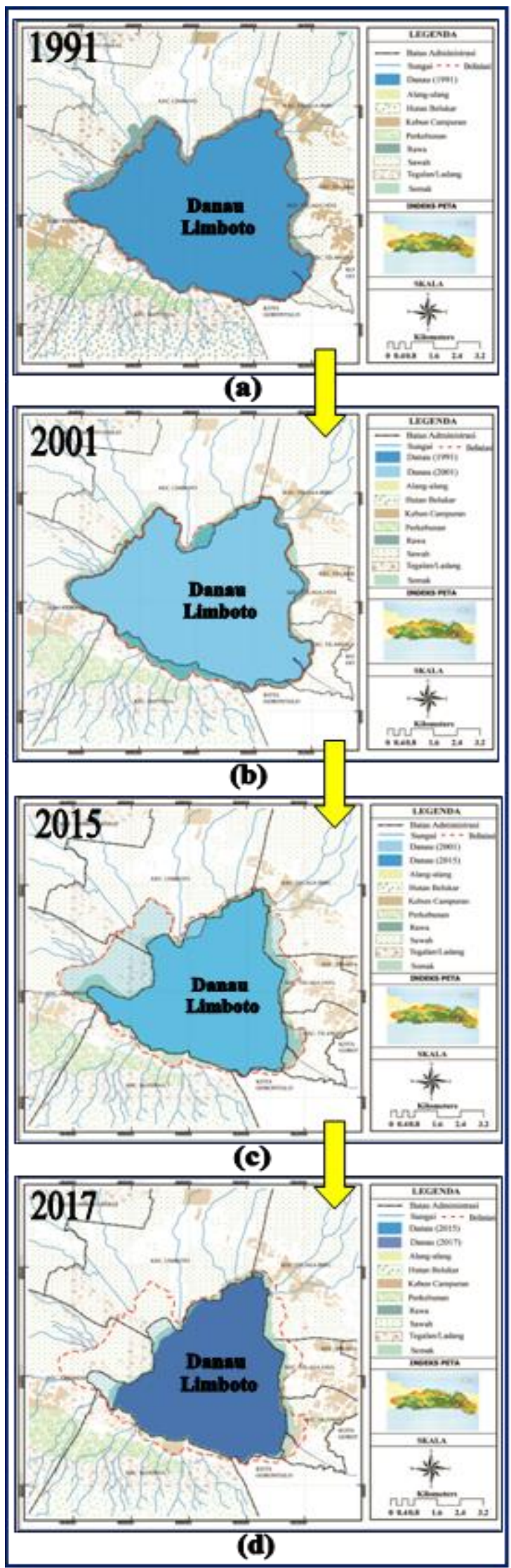

Gambar 5. Perubahan Penggunaan Lahan Danau Menjadi Lahan Pertanian dan Perkebunan di Sekitar Danau Limboto dari Tahun 1991 sampai dengan 2017 dalam 4 (Empat) Tahun Pengamatan

Sumber: Analisis Penulis, 2018 
Pada tahun 2015 (gambar 5 (c)) dapat dilihat bahwa luas Danau Limboto menyusut lagi dan lahan bekas penyusutan danau pada sebagian wilayah kecamatan yang berbatasan langsung dengan Danau Limboto berubah menjadi rawa, perkebunan, pertanian lahan basah dan pertanian lahan kering yang berupa tegalan dan kebun masyarakat. Sementara itu lahan yang sebelumnya pada tahun 2001 telah menjadi rawa pada tahun 2015 berubah penggunaannya menjadi lahan pertanian baik pertanian lahan basah (sawah), pertanian lahan kering (tegalan dan kebun campuran) maupun semak. Selanjutnya pada tahun 2017 (gambar 5 (d)) Danau Limboto kembali mengalami penyusutan tepatnya pada wilayah danau yang berbatasan dengan Kecamatan Limboto, Tabongo dan Tilango. Lahan danau yang berbatasan dengan wilayah kecamatan tersebut berubah menjadi rawa dan sebagiannya ada yang ditumbuhi oleh semak.

Berdasarkan uraian tersebut dapat dipahami bahwa secara fisik terjadi proses perubahan penggunaan lahan dari lahan danau menjadi lahan pertanian di sekitar Danau Limboto tepatnya pada lahan bekas penyusutan danau dari tahun 1991 sampai dengan tahun 2017. Proses perubahan penggunaan lahan danau menjadi lahan pertanian dan perkebunan terdiri dari 4 (empat) proses perubahan penggunaan lahan yaitu: (1) lahan danau yang menyusut berubah menjadi rawa kemudian berubah lagi menjadi lahan untuk pertanian lahan basah (sawah); (2) lahan danau yang menyusut berubah menjadi rawa kemudian berubah lagi menjadi lahan untuk pertanian lahan kering (tegalan); (3) lahan danau yang menyusut berubah menjadi rawa kemudian berubah lagi menjadi lahan untuk pertanian lahan kering (kebun campuran); dan (4) lahan danau yang menyusut berubah menjadi rawa kemudian berubah lagi menjadi lahan untuk perkebunan (kelapa). Uraian proses perubahan penggunaan lahan danau menjadi lahan pertanian dan perkebunan tersebut dapat dituangkan dalam bentuk skema berikut ini.

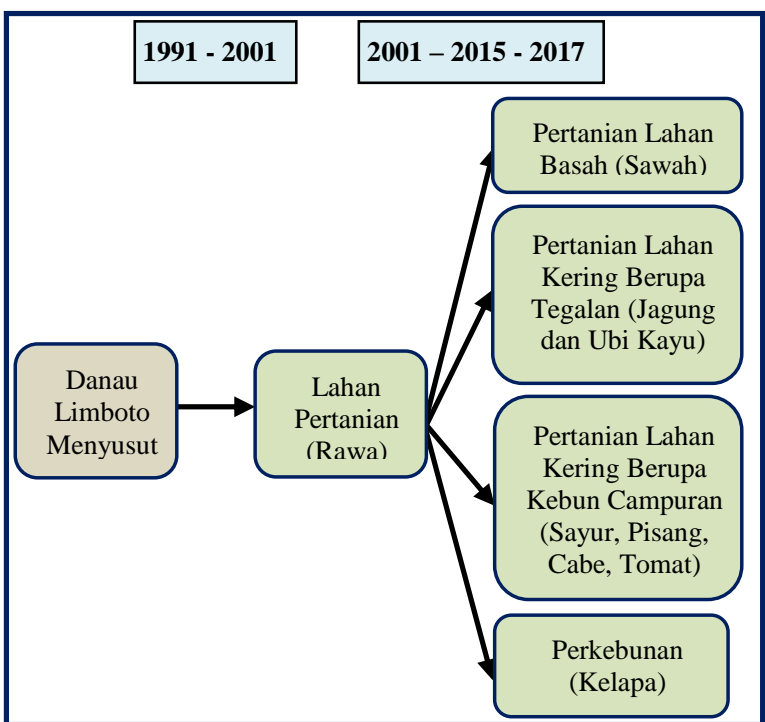

Gambar 6. Proses Perubahan Penggunaan Lahan Danau Menjadi Lahan Pertanian dan Perkebunan dari Tahun 1991 sampai dengan 2017

Sumber: Analisis Penulis, 2018

Proses perubahan penggunaan lahan danau menjadi lahan pertanian dan perkebunan berawal dari penyusutan yang terjadi di wilayah Danau Limboto. Penyusutan dan pendangkalan yang terjadi di wilayah Danau Limboto menyebabkan sebagian wilayah tepian danau berubah menjadi lahan pertanian berupa rawa yang kemudian lama kelamaan rawa tersebut semakin mengering, dan dilakukan pengkavlingan oleh masyarakat yang tinggal di sekitar Danau Limboto untuk diolah menjadi lahan pertanian masyarakat berupa sawah, tegalan untuk jagung dan ubi kayu, kebun untuk tanaman musiman, dan perkebunan kelapa. Perubahan penggunaan lahan danau menjadi lahan pertanian dan perkebunan di sekitar Danau Limboto di Kabupaten Gorontalo dapat dilihat pada hasil observasi dan dokumentasi di wilayah sekitar Danau Limboto yang merupakan lahan bekas penyusutan danau berikut ini. 


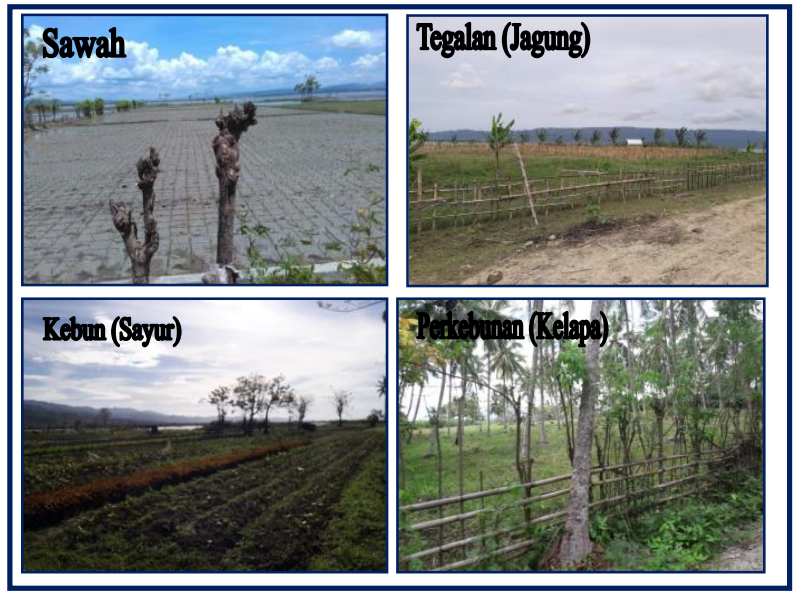

Gambar 7. Perubahan Penggunaan Lahan Danau Menjadi Lahan Pertanian dan Perkebunan di Sekitar Danau Limboto dari Tahun 1991 sampai dengan 2017 Sumber: Analisis Penulis, 2018

\section{Danau Menjadi Lahan Permukiman}

Proses perubahan penggunaan lahan secara fisik selanjutnya yaitu dari lahan danau menjadi lahan permukiman. Hasil analisis overlay dan digitasi jenis penggunaan lahan di sekitar Danau Limboto dari tahun 1991 sampai dengan tahun 2017 pada Tabel 1 dapat dilihat bahwa perubahan penggunaan lahan danau menjadi lahan permukiman dalam kurun waktu 26 (dua puluh enam) tahun tersebut sebesar 14,29 Ha atau sekitar 0,39\%. Berdasarkan pengamatan dan digitasi peta citra Landsat wilayah sekitar Danau Limboto tahun 1991, 2001, 2015, dan 2017 terjadi adanya perkembangan lahan permukiman dalam setiap tahun pengamatan tersebut. Lebih jelasnya dapat dilihat pada gambar 8 tentang perubahan penggunaan lahan di sekitar Danau Limboto dari tahun 1991 sampai dengan tahun 2017 yang ditinjau dalam 4 (empat) tahun pengamatan.

Pada Gambar 8 (a) dapat dilihat penggunaan lahan permukiman di sekitar Danau Limboto pada tahun 1991 dengan luas danau yang masih sekitar $\pm 3644,5 \mathrm{Ha}$. Selanjutnya pada tahun 2001 (gambar 8 (b)), seiring dengan penyusutan yang terjadi di Danau Limboto pada tahun tersebut juga terjadi perubahan penggunaan lahan danau menjadi lahan permukiman pada sebagian wilayah tepian danau khususnya pada wilayah danau yang berada di Kecamatan Batudaa, Tilango dan Telaga Jaya. Sebagian lahan permukiman tersebut berada pada lahan bekas penyusutan danau yang sebelumnya masih merupakan lahan danau pada tahun 1999. Sedangkan sebagian lain berada pada lahan penyusutan danau yang telah berubah penggunaannya menjadi lahan pertanian baik yang masih berupa rawa, sawah, tegalan dan kebun.

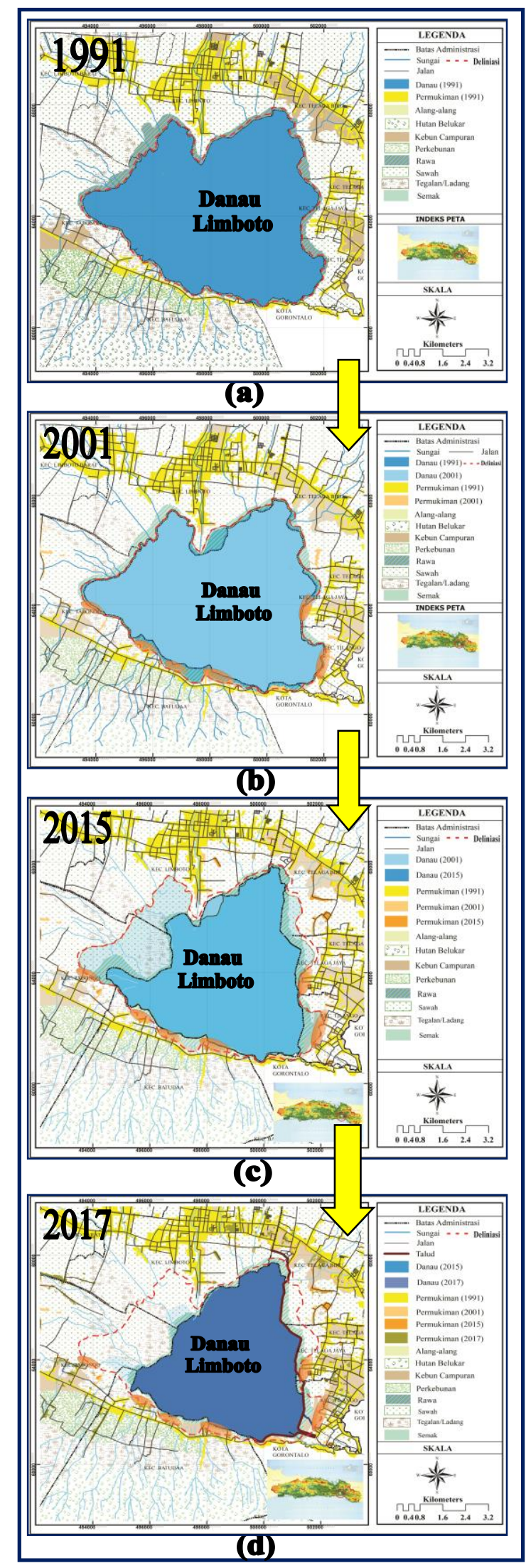

Gambar 8. Perubahan Penggunaan Lahan Danau Menjadi Lahan Permukiman di Sekitar Danau Limboto dari Tahun 1991 sampai dengan 2017 dalam 4 (Empat) Tahun Pengamatan

Sumber: Analisis Penulis, 2018 
Tahun 2015 (gambar 8 (c)) lahan permukiman semakin berkembang seiring dengan penyusutan yang kembali terjadi di Danau Limboto yang mana selain lahan permukiman yang dibangun oleh masyarakat juga pada tahun yang sama di lahan bekas penyusutan danau yang telah berubah menjadi rawa dan sawah pada tahun 2001, pada tahun 2015 lahan tersebut dibangun perumahan untuk nelayan yang tinggal di sekitar Danau Limboto yang belum memiliki tempat tinggal. Perumahan tersebut berasal dari pemerintah melalui Program Keluarga Harapan yang dibangun di lokasi yang berdekatan dengan Danau Limboto di wilayah kecamatan Tilango, Telaga Jaya, Telaga Biru dan Limboto. Selanjutnya pada tahun 2017 (gambar 5.8 (d)) Danau Limboto kembali menyusut namun penyusutannya tidak begitu signifikan dibandingkan dengan penyusutan yang terjadi pada tahun 2015. Pada tahun 2017 tersebut juga terlihat adanya perkembangan lahan permukiman di sekitar Danau Limboto. Perkembangan lahan permukiman tersebut ada yang berkembang diatas lahan yang awalnya merupakan danau yang kemudian menjadi rawa, sawah, kebun, dan juga tegalan.

Berdasarkan uraian tersebut dapat dipahami bahwa terjadi proses perubahan penggunaan lahan danau menjadi lahan permukiman di sekitar Danau Limboto tepatnya pada lahan bekas penyusutan danau dari tahun 1991 sampai dengan tahun 2017. Adapun proses perubahan penggunaan lahan danau menjadi lahan permukiman terdiri dari 4 (empat) proses perubahan penggunaan lahan yaitu: (1) lahan danau yang menyusut berubah menjadi rawa kemudian berubah lagi menjadi lahan untuk pertanian lahan basah (sawah) yang selanjutnya sawah tersebut kemudian berubah menjadi lahan permukiman; (2) lahan danau yang menyusut berubah menjadi rawa kemudian berubah lagi menjadi lahan untuk pertanian lahan kering (tegalan dan kebun) yang selanjutnya berubah menjadi lahan permukiman; (3) lahan danau yang menyusut berubah menjadi rawa kemudian berubah lagi menjadi lahan permukiman; dan (4) lahan danau yang menyusut yang secara langsung berubah menjadi lahan permukiman. Uraian proses perubahan penggunaan lahan danau menjadi lahan permukiman tersebut kemudian dapat disajikan dalam bentuk skema berikut ini.

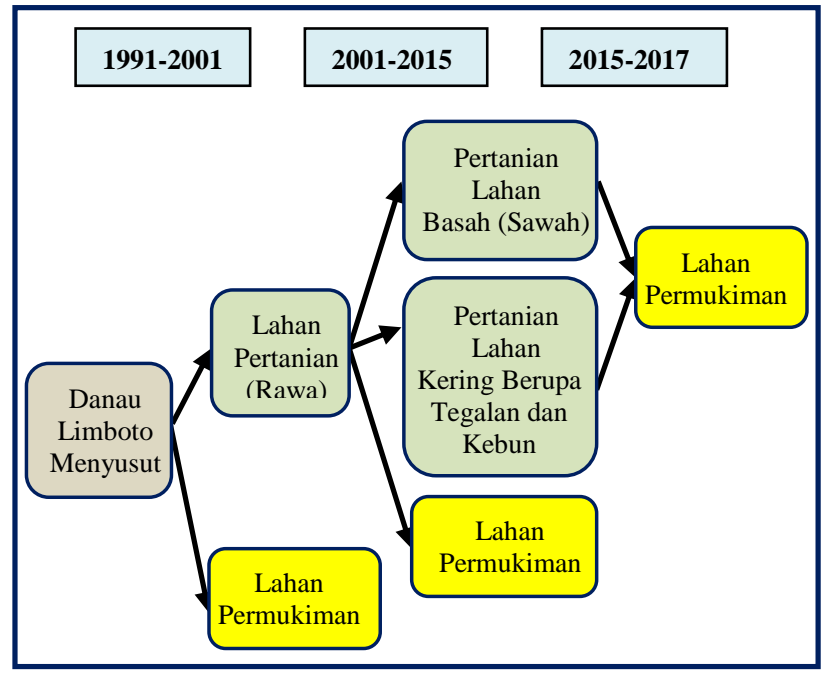

Gambar 9. Proses Perubahan Penggunaan Lahan Danau Menjadi Lahan Permukiman dari Tahun 1991 sampai dengan 2017

Sumber: Analisis Penulis, 2018

Proses perubahan penggunaan lahan danau menjadi lahan permukiman juga berawal dari penyusutan dan pendangkalan Danau Limboto. Hal tersebut menyebabkan sebagian wilayah tepian danau berubah menjadi lahan pertanian berupa rawa yang kemudian lama kelamaan rawa tersebut semakin mengering dan diolah menjadi lahan pertanian oleh masyarakat di sekitar Danau Limboto yang kemudian apabila terdapat anggota keluarga yang membutuhkan tempat tinggal sebagian dari lahan pertanian masyarakat (sawah, tegalan, dan kebun) tersebut diubah menjadi lahan untuk membangun tempat tinggal sehingga terjadi proses perubahan dari lahan danau menjadi lahan pertanian dan kemudian berubah lagi menjadi lahan permukiman. Hal ini dikarenakan kebutuhan masyarakat akan tempat tinggal seiring dengan peningkatan jumlah penduduk yang terjadi di suatu wilayah khususnya di wilayah sekitar Danau Limboto sehingga anggota keluarga yang belum memiliki tempat tinggal oleh keluarganya akan diusahakan untuk memiliki tempat tinggal yang berdekatan mengingat sistem keluarga yang ada dalam masyarakat tersebut sejak dulu. Selain itu adanya suatu keinginan masyarakat nelayan untuk memiliki tempat tinggal yang berdekatan dengan lokasi mata pencaharian mereka sebagai nelayan Danau Limboto menyebabkan lahan permukiman pada lahan bekas penyusutan danau semakin berkembang. Hal tersebut dapat dilihat dari hasil hasil observasi dan 
dokumentasi di wilayah sekitar Danau Limboto berikut ini.

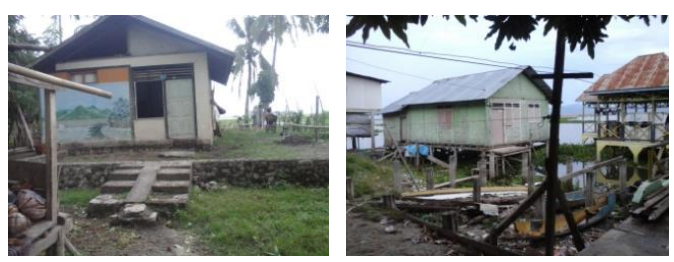

Gambar 10. Perubahan Penggunaan Lahan Danau Menjadi Lahan Permukiman di Sekitar Danau Limboto dari Tahun 1991 sampai dengan 2017 Sumber: Analisis Penulis, 2018

\section{Danau Menjadi Kawasan Wisata}

Proses perubahan penggunaan lahan secara fisik yang terjadi di sekitar Danau Limboto tidak hanya dari lahan danau menjadi lahan pertanian dan perkebunan, dan lahan permukiman namun juga dari lahan danau menjadi kawasan wisata. Berdasarkan analisis overlay dan digitasi peta citra kawasan sekitar Danau Limboto dapat dilihat bahwa penggunaan lahan di sekitar Danau Limboto pada tahun 2017 (Tabel 1) juga mengalami perubahan penggunaan lahan dari lahan danau menjadi kawasan wisata yaitu sebesar $\pm 0,35 \mathrm{Ha}$ atau sekitar $0,01 \%$. Dari pengamatan hasil digitasi peta citra Landsat wilayah sekitar Danau Limboto tahun 1991, 2001, 2015, dan 2017 terjadi perubahan penggunaan lahan danau menjadi kawasan wisata. Lebih jelasnya perubahan penggunaan lahan dari lahan danau menjadi kawasan wisata dapat dilihat pada gambar 10 .

Gambar 10 (a) dapat dilihat terjadi penyusutan Danau Limboto dari tahun 1991 sampai dengan tahun 2001. Namun belum terlihat adanya perubahan penggunaan lahan bekas penyusutan danau menjadi kawasan wisata. Selanjutnya pada tahun 2015 (gambar 10 (b)), pada wilayah tepian Danau Limboto tepatnya pada lahan dulunya merupakan danau sudah terlihat perubahan penggunaan lahan menjadi kawasan wisata. Pada tahun 2017 (gambar 10 (c)), pada bagian wilayah di sekitar kawasan wisata tidak mengalami penyusutan luas dari tahun 2015 dan juga pada tahun 2017 luas kawasan wisata cenderung tetap seperti luas kawasan wisata pada tahun 2015. Proses perubahan pengguanaan lahan danau menjadi kawasan wisata lebih jelasnya dapat dilihat dalam bentuk skema berikut ini.

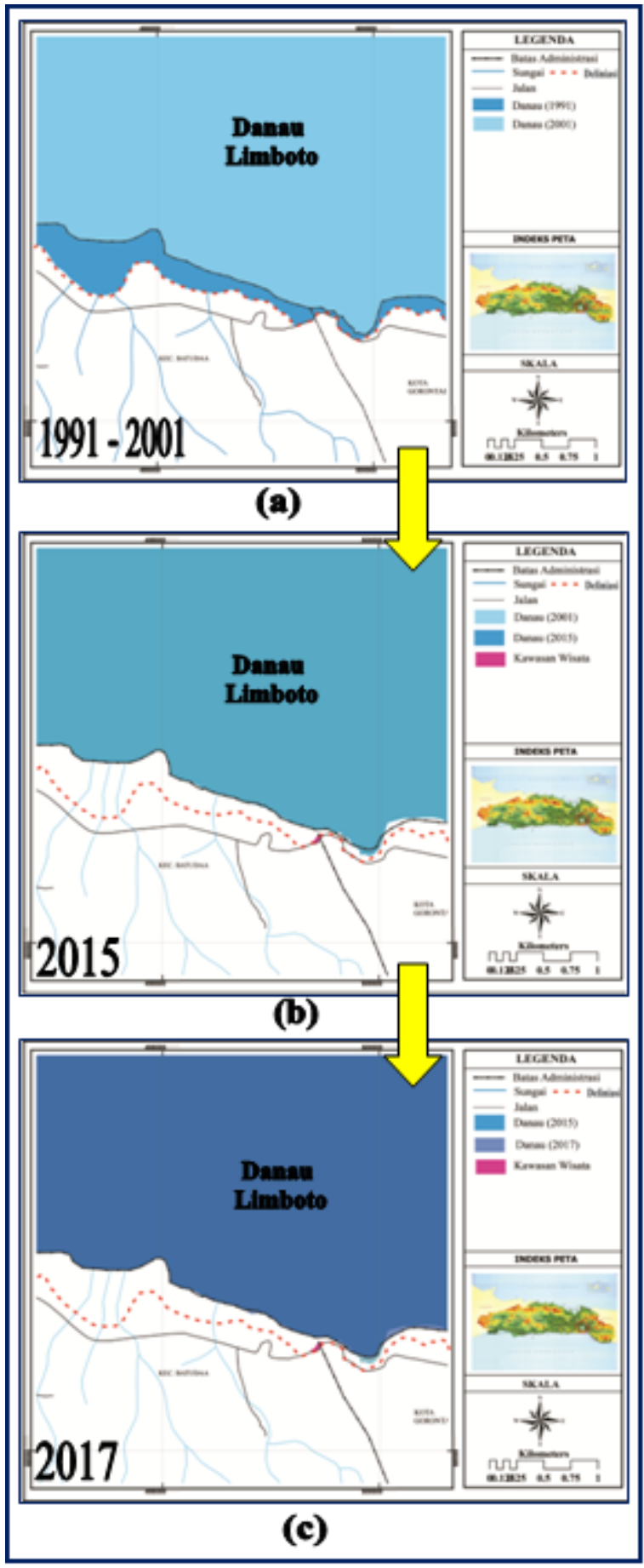

Gambar 9. Perubahan Penggunaan Lahan

Danau Menjadi Kawasan Wisata di Sekitar

Danau Limboto dari Tahun 1991 sampai dengan 2017 dalam 4 (Empat) Tahun Pengamatan

Sumber: Analisis Penulis, 2018

Berdasarkan uraian tersebut dapat dipahami bahwa proses perubahan penggunaan lahan secara fisik di sekitar Danau Limboto juga terjadi proses perubahan penggunaan lahan danau menjadi kawasan wisata. Proses perubahan penggunaan lahan danau menjadi kawasan wisata terjadi secara langsung yang mana 
lahan danau menyusut dan langsung berubah menjadi kawasan wisata tanpa adanya perubahan ke jenis penggunaan lain pada tahapan sebelumnya seperti pada skema berikut ini.

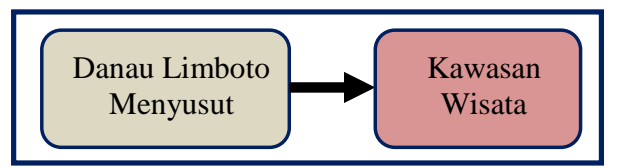

Gambar 10. Proses Perubahan Penggunaan Lahan

Danau Menjadi Kawasan Wisata

dari Tahun 1991 sampai dengan 2017

Sumber: Analisis Penulis, 2018

Proses perubahan penggunaan lahan danau menjadi kawasan wisata juga berawal dari penyusutan dan pendangkalan di Danau Limboto. Hal tersebut dimanfaatkan oleh pemerintah dalam melakukan pengembangan fasilitas kawasan wisata Museum Pendaratan Soekarno di wilayah tepian Danau Limboto yang mana pada saat itu tepatnya pada awal tahun 2000an pemerintah melakukan revitalisasi rumah peristirahatan Presiden Soekarno untuk dijadikan museum.

Berdasarkan hasil pembahasan tersebut dapat dipahami bahwa perubahan penggunaan lahan di sekitar Danau Limboto merupakan perubahan penggunaan lahan dari lahan danau menjadi lahan bukan danau yang mana terbagi dalam 3 (tiga) proses perubahan yaitu proses perubahan lahan danau menjadi lahan pertanian, lahan danau menjadi lahan permukiman dan lahan danau menjadi kawasan wisata.

\section{KESIMPULAN}

Perubahan penggunaan lahan merupakan suatu kegiatan pengalihan fungsi lahan dari lahan suatu jenis penggunaan ke jenis penggunaan lain sesuai dengan kepentingan manusia selaku pengguna lahan. Penyusutan yang terjadi di Danau Limboto yang disebabkan oleh sedimentasi sungai memicu terjadinya perubahan penggunaan lahan bekas penyusutan danau yang mengakibatkan lahan yang awalnya danau berubah penggunaannya. Berdasarkan hasil analisis dapat dilihat bahwa bentuk perubahan penggunaan lahan danau menjadi lahan bukan danau di sekitar Danau Limboto di Kabupaten Gorontalo dari tahun 1991 sampai dengan tahun 2017 yaitu sebesar $\pm 936,56 \mathrm{Ha}(25,69 \%)$ menjadi lahan pertanian dan perkebunan, 14,29 $\mathrm{Ha}$ $(0,39 \%)$ menjadi lahan permukiman, dan $0,35 \mathrm{Ha}$ $(0,39 \%)$ menjadi kawasan wisata. Perubahan penggunaan lahan danau menjadi lahan bukan danau tersebut mengakibatkan luas lahan danau menjadi berkurang yang mana hal tersebut dapat mengancam keberlanjutan dari Danau Limboto di masa mendatang.

Perubahan penggunaan lahan yang terjadi di sekitar Danau Limboto terjadi secara bertahap. Berdasarkan hasil pengamatan dalam beberapa titik waktu amatan yaitu tahun 1991, 2001, 2015, dan 2017 wilayah sekitar Danau Limboto di Kabupaten Gorontalo memperlihatkan adanya suatu fenomena proses perubahan penggunaan lahan secara fisik dari waktu ke waktu. Proses perubahan penggunaan lahan yang terjadi di sekitar Danau Limboto yaitu proses perubahan penggunaan lahan secara horizontal yang mana dalam setiap bentuk perubahan penggunaan lahan danau menjadi lahan bukan danau terdiri dari beberapa proses perubahan, yaitu:

a. Lahan danau menjadi lahan pertanian dan perkebunan terdiri dari 4 (empat) proses perubahan yaitu lahan danau berubah menjadi rawa kemudian berubah menjadi lahan pertanian untuk lahan basah, lahan kering (tegalan dan kebun campuran, dan perkebunan (kelapa).

b. Lahan danau menjadi lahan permukiman terdiri dari 4 (empat) proses perubahan yaitu lahan danau berubah menjadi lahan pertanian (rawa) kemudian berubah menjadi lahan permukiman, lahan danau berubah menjadi rawa kemudian berubah menjadi sawah kemudian berubah menjadi lahan permukiman, lahan danau berubah menjadi rawa kemudian berubah menjadi kebun dan tegalan kemudian berubah menjadi lahan permukiman, dan lahan danau yang langsung berubah menjadi lahan permukiman.

c. Lahan danau berubah menjadi kawasan wisata.

Berdasasarkan uraian proses diatas dapat dipahami bahwa perubahan penggunaan lahan di sekitar Danau Limboto yaitu perubahan penggunaan lahan dari kawasan yang bersifat lindung menjadi budidaya. Hal tersebut apabila dilihat dalam UU No 26 Tahun 2007 terjadi suatu penyimpangan dalam penataan ruang wilayah. Selain itu hal perubahan penggunaan lahan danau 
tersebut apabila dibiarkan begitu saja dapat mengancam keberlanjutan danau tersebut. Kebutuhan manusia terhadap lahan dalam memenuhi kebutuhan hidupnya baik untuk tempat tinggal, sumber pendapatan, dan sebagai tempat untuk berinteraksi dengan manusia lain menjadi salah satu penyebab perubahan penggunaan lahan di sekitar Danau Limboto. Selain itu tidak adanya batasan fisik wilayah danau yang dipertahankan sejak tahun 1990an mengakibatkan penggunaan lahan di tepian danau semakin tidak terkontrol. Pemerintah kurang efektif dalam melakukan pengendalian terhadap penggunaan lahan di sekitar Danau Limboto.

Berdasarkan uraian kesimpulan diatas maka terdapat rekomendasi dari penelitian ini yang ditujukan kepada pemerintah, praktisi, dan bagi penelitian selanjutnya. Rekomendasi pertama yaitu kepada pemerintah Provinsi Gorontalo khususnya pemerintah Kabupaten Gorontalo yang sekitar $\pm 70 \%$ wilayah danau merupakan wilayah administrasi Kabupaten Gorontalo. Kebijakan pemerintah terkait penggunaan lahan di sekitar Danau Limboto harus mempertimbangkan keberlanjutan dari Danau Limboto mengingat Danau Limboto merupakan salah satu asset bagi Provinsi Gorontalo khususnya Kabupaten Gorontalo. Selain itu perlu adanya intervensi dari pemerintah terkait manajemen lingkungan danau dan sekitarnya. Hal ini karena Danau Limboto memiliki peran penting bagi Kabupaten Gorontalo sebagai sumber pengairan bagi wilayah sekitarnya, sumber mata pencaharian bagi masyarakat, penampung air hujan, dan juga dapat menjadi daya tarik bagi wisatawan. Hal tersebut harusnya menjadi perhatian penting dari pemerintah dalam mengembangkan potensi yang ada pada Danau Limboto tanpa mengesampingkan aspek keberlanjutan agar danau tersebut bisa dinikmati oleh para generasi penerus di masa yang akan datang.

Rekomendasi kedua yaitu untuk para praktisi yang mana harus mempertimbangkan aspek keberlanjutan dalam melakukan analisis terkait perencanaan wilayah di sekitar Danau Limboto. Perencana harus mampu menghasilkan suatu perencanaan yang dapat mengakomodir semua hal terkait dengan penggunaan lahan di sekitar danau baik dari sisi masyarakat, pemerintah dan pemangku kepentingan lain agar tercipta suatu keserasian dalam penggunaan lahan di sekitar Danau Limboto tanpa memberikan dampak negatif terhadap keberlanjutan Danau Limboto di masa yang akan datang.

Rekomendasi terakhir yaitu buat para peneliti selanjutnya yang ingin meneliti terkait perubahan penggunaan lahan di sekitar Danau Limboto Kabupaten Gorontalo. Analisis perubahan penggunaan lahan di sekitar Danau Limboto diharapkan mampu menjadi masukan bagi penelitian selanjutnya. Penelitian ini masih terdapat banyak kekurangan. Dalam penelitian ini secara umum telah membahas jenis dan proses perubahan penggunaan lahan di sekitar Danau Limboto namun pembahasan proses dalam penelitian ini masih sebatas pada pembahasan proses perubahan penggunaan lahan secara fisik dari tahun 1991 sampai dengan tahun 2017. Penelitian terkait proses perubahan penggunaan lahan di sekitar Danau Limboto secara nonfisik yang terkait aspek sosial juga perlu dilakukan. Diharapkan dengan adanya penelitian tersebut dapat menjadi masukan dan bahan pertimbangan dalam melakukan perencanaan yang terkait penggunaan lahan di sekitar Danau Limboto untuk meminimalisir dampak negatif yang mengancam keberlanjutan dari Danau Limboto di masa mendatang.

\section{DAFTAR PUSTAKA}

Arminah, Valentina, 2012. Model Spasial Penggunaan Lahan Pertanian Berkelanjutan di Kecamatan Kledung Kabupaten Temanggung. Yogyakarta : STPN Press

Arsyad, Sitanala, 2010. Konservasi Tanah dan Air. Edisi Kedua. IPB Press. Bogor

Menteri Pekerjaan Umum dan Perumahan Rakyat RI, 2015. Peraturan Menteri Pekerjaan Umum dan Perumahan Rakyat Republik Indonesia Nomor 28/PRT/M/2015 Tentang Penetapan Garis Sempadan Sungai dan Garis Sempadan Danau. Jakarta : Kementerian Pekerjaan Umum

Moleong, Lexy J, 2006. Metodologi Penelitian Kualitatif. Bandung : PT Remaja Rosdakarya

Panwar, Shikha dan DS, Malik, 2017. Evaluating Land Use/Land Cover Change Dynamics in Bhimtal Lake Catchment Area, Using Remote Sensing and GIS Techniques. Journal of Remote Sensing and GIS. ISSN : 2469-4134, Vol 6, Issue 2. Hal. 1 - 4. Department of Zoology and Environmental Science, 
Gurukula Kangri University, Harldwar, UK, India.

Pemerintah RI, 2007. UU No 26 Tahun 2007 Tentang Penataan Ruang. Jakarta : Pemerintah RI

Wahyunto, Sunaryo, Priyono, Adi, dan Abidin, M Zainal, 2001. Studi Perubahan Penggunaan Lahan Di Sub DAS Citarik, Jawa Barat dan DAS Kaligarang, Jawa Tengah. Prosiding Seminar Nasional Multifungsi Lahan Sawah. Bogor: Balai Penelitian Tanah. Hal $39-63$.

Yunus, Hadi Sabari, 2001. Perubahan Pemanfaatan Lahan di Daerah Pinggiran Kota (Kasus di Pinggiran Kota Yogyakarta). Disertasi. Fakultas Geografi Universitas Gadjah Mada. Yogyakarta : UGM 
